\title{
JUURNAL.RU
}

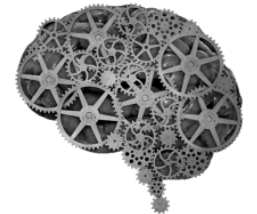

COMPANY GROUP "INTELLEKT"

Бойко Н.В., Быкова В.В. Ростовский государственный медицинский университет Ростов-на-Дону, Россия

doi: 10.18411/1j2016-3-06

\section{Эпидемиология носовых кровотечений}

Носовые кровотечения (НК) по частоте возникновения занимают первое место среди спонтанных кровотечений $[1,2,3]$.

Анализ структуры госпитализированных в ЛОР клинику РостГМУ больных показывает неуклонный рост доли больных с НК как в общем количестве, так и в скоропомощной группе (в таблице 1 приведены выборочные цифры с интервалом 3 года).

Таблииа 1

Относительные показатели количества больных с носовым кровотечением по материалам ЛОР клиники РостГМУ.

\begin{tabular}{|l|c|c|c|c|c|}
\hline & 2003 & 2006 & 2009 & 2012 & 2015 \\
\hline $\begin{array}{l}\text { \% НК от общего количества } \\
\text { госпитализированных } \\
\text { больных }\end{array}$ & 7,2 & 7,7 & 8,4 & 10,3 & 11,4 \\
\hline $\begin{array}{l}\text { \% НК от количества } \\
\text { больных, } \\
\text { госпитализированных по } \\
\text { экстренным показаниям }\end{array}$ & 9,1 & 10,4 & 9,8 & 11,6 & 12,7 \\
\hline
\end{tabular}


Рост числа больных с НК особенно нагляден при сопоставлении с показателями 1999 года, когда больные с НК составляли 4,2\% от общего числа больных ЛОР клиники и 5,4\% от количества экстренно госпитализированных [4].

Среди больных с НК преобладали лица пожилого возраста (48,8\%), однако доля больных зрелого, трудоспособного возраста тоже не мала - 37,8\%. Реже нуждались в госпитализации больные юношеского - до 20 лет и старческого возраста - старше 75 лет(6,5 и 6,9\% соответственно).

Большую часть больных с НК составили женщины - 56,9\%. В юношеском возрасте представительство мужчин и женщин было равным. В первой половине зрелого возраста (21-40 лет) количество мужчин вдвое превосходило число женщин, что, по всей вероятности, можно объяснить ангиопротективным действием эстрогенов у женщин фертильного возраста. В зрелом возрасте (41-60 лет) число мужчин и женщин вновь выровнялось. В пожилом и старческом возрасте (старше 61 года) количество женщин вдвое превышало число мужчин, что, предположительно, обусловлено меньшей продолжительностью жизни лиц мужского пола.

Для оценки зависимости частоты возникновения НК от возраста использован корреляционный анализ. Коэффициент корреляции оказался равным 0,879 , что свидетельствует о наличии зависимости частоты возникновения НК от возраста больного с вероятностью ошибки $\mathrm{p}<0,05$.

Наблюдается увеличение количества больных с носовыми кровотечениями в осенне-зимний период с пиками в ноябре и феврале и спад в июле-августе.

Этиологическая структура заболеваемости остается постоянной и не зависит от сезона. Чаще всего причиной НК была артериальная гипертензия (52,1\%). В эту группу мы объединили больных гипертонической болезнью и симптоматическими гипертониями. Второе место по частоте занимают посттравматические НК, куда отнесены бытовые травмы (12,8\%). В группу дистрофических заболеваний полости носа (5\%) включены сухой передний 
ринит, перфорация перегородки носа, атрофический ринит, искривление перегородки носа. Группу инфекционных заболеваний $(2,4 \%)$ составили больные острыми респираторно-вирусными инфекциями. Сюда, разумеется, попали и случаи медикаментозных НК, связанных с приемом нестероидных противовоспалительных препаратов и антикоагулянтов [5]. К ятрогенным НК $(0,9 \%)$ отнесены кровотечения после различных эндоназальных вмешательств и манипуляций, выполненных в поликлиниках (ультразвуковая дезинтеграция нижних носовых раковин, пункция верхнечелюстной пазухи, инъекционное склерозирование нижних носовых раковин и др.), а также больные с патологией сердечно - сосудистой системы, длительно принимающие антикоангулянты. В 0,7\% случаев НК были обусловлены наличием новообразований в полости носа и околоносовых пазухах: гемангиом, ангиоматозных полипов, рака. В числе редко встречающихся причин НК были острый лейкоз, дебютировавший носовыми кровотечениями, гемофилия, болезнь Рандю-Ослера-Вебера, острый ДВС-синдром, развившийся в послеродовом периоде и на фоне массивной кровопотери. В 16,5\% случаев точно установить причину НК не удалось.

Точное определение причины НК имеет важное значение для определения тактики лечения данного заболевания $[6,7,8]$. 


\section{Литература:}

1. Анготоева И.Б., Курлова А.В., Горносталев Н.Я. Методы остановки носовых кровотечений. Рос. ринология. 2012. Т. 20. № 3. С. 24-30.

2. Гаджимирзаев Г.А., Тулкин В.Н., Гаджимирзаев Р.Г. Носовые кровотечения. Аналитический обзор и собственный опыт. Рос. оторинолар. 2014. Т. 72 . № 5. C. 96-110.

3. Волков А.Г., Бойко Н.В., Быкова В.В., Жданов В.Г. Совершенствование способов остановки носового кровотечения. Вестник оторинолар. 2010. № 4. C. 9-12.

4. Бойко Н.В. Хирургическое лечение рецидивирующих носовых кровотечений. Рос. ринология 1999. № 2. С. 29.

5. Бойко Н.В. Носовые кровотечения как осложнение антитромботической терапии. Рос. ринология 2011. Т. 19. № 4. С. 29-32.

6. Бойко Н.В., Шатохин Ю.В., Быкова В.В. Патогенетическое лечение рецидивирующих носовых кровотечений на фоне гипертонической болезни. Рос. ринология 2007. № 2. С. 58.

7. Бойко Н.В., Шатохин Ю.В. Алгоритм оказания неотложной помощи больным с носовым кровотечением. Рос. ринология. 2008. Т. 16. № 1. С. 4144.

8. Бойко Н.В., Колмакова Т.С., Быкова В.В. Биохимические показатели анемии у больных с носовыми кровотечениями. Вестник оторинолар. 2010. № 4. C. 13-16. 